\title{
The Implementation of Social Studies Learning Model Based on Cultural Intelligence
}

\author{
S Suharli* \\ Economic Education \\ Universitas Samawa \\ Sumbawa Besar, Indonesia \\ 5uharli.uns4@gmail.com
}

\author{
Nining Andriani \\ Economic Education \\ Universitas Samawa \\ Sumbawa Besar, Indonesia \\ nininga818@gmail.com
}

\author{
F Fatmawati \\ Economic Education \\ Universitas Samawa \\ Sumbawa Besar, Indonesia \\ fatmawatifkip0@gmail.com
}

\begin{abstract}
Ethnic, cultural and religious diversity used to be the cause of conflict in society. Therefore, cultural intelligence is an indispensable competency, including the multi-ethnic Sumbawa community. The application of a cultural intelligencebased social intelligence learning model is carried out so that students have awareness and knowledge of religious and cultural diversity, have the motivation to work with friends of different religions and cultures and have tolerant behaviour towards friends of different religions and cultures. This research was conducted through the Isman learning design model. This research is still at the development stage, namely the limited trial stage conducted in class VIII at a SMPN in Sumbawa, Indonesia. The data were gathered by using questionnaires, interviews, observation, and documentation. The data analysis used descriptive qualitative techniques. The research findings are classified into five; (a) the input stage, describing the initial conditions of social studies learning; (b) the process stage, which describes the implementation of social studies learning based on cultural intelligence by both teachers and students; (c) the output stage, explaining the results of the implementation of the social studies learning model based on cultural intelligence both the level of involvement and learning outcomes of students; (d) the feedback stage, describes the process of evaluation and revision of the implementation of the learning syntax; and learning stages, describing the stages or syntax of the social studies learning model based on cultural intelligence.
\end{abstract}

Keywords-Cultural Intelligence, Learning Model, Social Studies Education

\section{INTRODUCTION}

Academically, social studies education provides support towards the creation of good citizens. Social studies is a part of the school curriculum whose main responsibility is to assist students in developing the knowledge, skills, attitudes, values needed to participate in community life both at the local, national and global levels [1].

One of the life skills that students have in the 21 st century in facing the rapid development of Science, Technology and Arts and the influence of globalization which is marked by the entry of external cultures that are not necessarily compatible with local culture is cultural literacy and citizenship [2].

The implementation of the social studies learning model based on cultural intelligence is based on the factual conditions of the Sumbawa people. Sumbawa is one of the districts in West Nusa Tenggara which has a very plural community composition. The Tau Samawa (Sumbawa people) who currently inhabit the Sumbawa district are a mixture of many ethnic groups over the centuries. In 1920, of the 97,000 inhabitants of the Sumbawa kingdom, 57,000 were a mixture of indigenous people with the Bugis-Makassar ethnic group and 24,000 were immigrants from Sumatra, Banjar, Sasak, Java, Bali, and Bima [3].

Geographically, Sumbawa Regency is located in a strategic position, which is in the golden triangle of the tourism area between the islands of Bali, Lombok and Komodo Island. The total population is 452,746 people, (male 228,717 and female 224,029). While the number of indigenous people (ethnic Samawa) reached $68.66 \%$ and the rest are ethnic Balinese, Sasak (Lombok), Javanese, Sundanese, Madurese, Mbojo (Bima / Dompu), Bugis Makasar, Mandar, Minang, Sumba or Timor. and Arabic [4].

Cultural and religious differences are the source of conflict. Another factor as a cause is the low level of cultural intelligence and the lack of consideration of racial, ethnic and cultural differences in the patterns of interaction and behavior in a multi-ethnic community environment. The current challenge for most organizations has shifted to multicultural issues, and cultural intelligence is the best way that can be used to deal with multicultural situations and is considered one of the important abilities in the management of cultural differences [5]. Cultural intelligence (CQ) is a person's ability to function effectively in situations characterized by cultural diversity [6].

One of the strategic efforts in developing understanding, tolerance and mutual understanding is through education [7]. The social studies learning model based on cultural intelligence is a new construction that refers to a social learning model and is developed into several stages of learning, namely concrete experience, reflection, sharing, teamwork, and presentation. The social learning model stated by Joyce and Weil is "a group learning model that emphasizes human social behavior, studies social behavior, and enhances academic learning outcomes through learning that is oriented towards academic collaboration, prepares students to be good citizens, and forming a satisfying social life [8]. 
Thus, the social studies learning process must be able to make social problems a source of learning in an effort to form community members who are sensitive and care about the environmental situation they face. Cultural intelligence-based social studies learning has a great capacity and can involve students in learning about and for social justice. In a multicultural classroom context, the implementation of social studies learning based on cultural intelligence is able to achieve the ability to function and manage interactions in situations of cultural differences of students. Based on the context and conditions of the Sumbawa people, the implementation of the social studies learning model based on cultural intelligence in Sumbawa district is felt to be done.

\section{METHODS}

The research subjects consisted of 90 students, 1 social studies teacher and the principal. The implementation of the social studies learning model based on cultural intelligence was carried out in class VIII at a junior high school in Sumbawa, Indonesia. The implementation of the learning model refers to the Isman instructional design model. The Isman model is a five-step systematic planning process consisting of the input, process, output, feedback, and learning stages [9]. Data collection techniques in this study using observation, interviews and documentation. While the data analysis technique used a qualitative descriptive analysis technique [10]. The flow of the implementation of the learning model is as listed in the following figure:

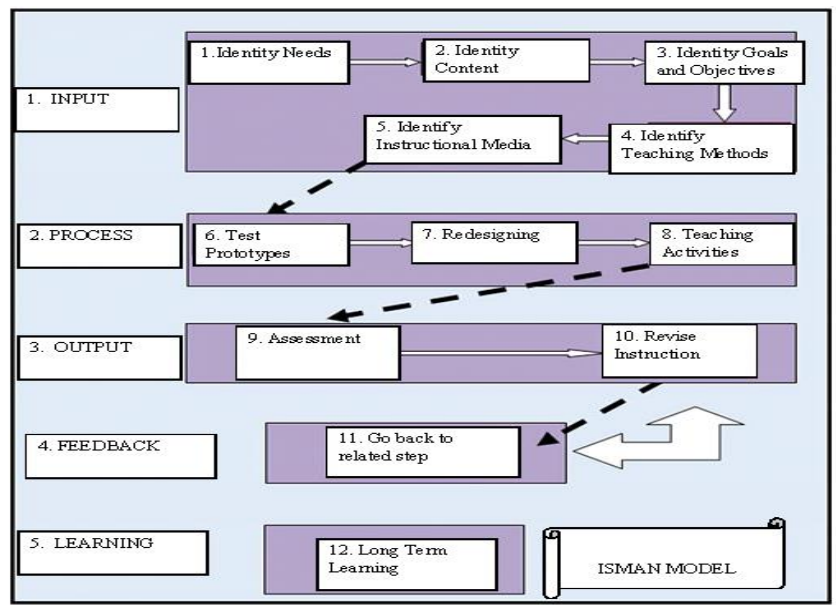

Fig. 1. Isman instructional design model (2011)

\section{RESULT AND DISCUSSION}

\section{A. Input Stage.}

Based on the results of observations on learning activities in social studies subjects, it was found (1) the teacher was still very dominant in providing explanations of the material using the lecture method; (2) the conditions of community diversity and social problems have not been maximally utilized as a source of social studies learning and as material for student discussion in the classroom; (3) the evaluation technique used is still predominantly using written tests; (4) social mobility and plurality of Indonesian society cannot be used as a relevant subject matter in increasing the cultural intelligence competence of students; (5) the syntax of the social studies learning model based on cultural intelligence consists of: experience, reflection, sharing, teamwork, and presentation.

\section{B. Process Stage}

The social studies learning model based on cultural intelligence was not developed based on certain cultures in Sumbawa, but was based on the theory of cultural intelligence developed by Soon Ang and Linn Van Dyne [11]. However, the social studies learning model based on cultural intelligence that was developed is still in line with the concept of saleng (mutual) in Sumbawa culture. The concept of saleng (mutual) in Sumbawa culture is a form of mutual respect and respect for differences [3].

The implementation of the social studies learning model based on cultural intelligence was carried out ten times. Each learning activity ends, together with the teacher then evaluates and revises, conducts discussions and makes recommendations as material for improving the learning design at the next meeting. The evaluation process is carried out through reflection activities on the implementation of learning syntax. Overall, the syntax implementation of the social studies learning model based on cultural intelligence can be carried out well by teachers and students. The implementation of all learning syntax is reflected in the ability of the teacher to understand and translate the learning plan into the implementation process in every meeting of the learning process. Most of the students in different class categories showed active involvement in various learning activities designed by the teacher. The involvement of students in sharing activities, helping each other, self-confidence, responsibility, mutual respect, caring, enjoying learning activities together, learning from other students, and appreciating the existence of other students as part of a team is a reflection of cultural intelligence. students are well formed.

\section{Output Stage}

The implementation of the social studies learning model based on cultural intelligence is indicated by an increase in the involvement of students at each learning stage with indicators of cultural intelligence that appear in the activities carried out. Based on the data from the evaluation results on the level of involvement and learning ability of students, it shows that the increase in the percentage of students' involvement in learning and learning outcomes has met the minimum completeness criteria.

TABLE I. THE LEVEL OF INVOLVEMENT OF STUDENTS IN LEARNING

\begin{tabular}{|c|c|c|c|c|}
\hline Class & Meeting 1 & Meeting 2 & Meeting 3 & $\begin{array}{c}\text { Meeting } \\
\mathbf{4}\end{array}$ \\
\hline Class A & $51,61 \%$ & $70,97 \%$ & $77,42 \%$ & $77,42 \%$ \\
\hline Class B & $53,33 \%$ & $66,67 \%$ & $76,67 \%$ & $76,67 \%$ \\
\hline Class C & $72,41 \%$ & $75,86 \%$ & & \\
\hline
\end{tabular}

TABLE II. STUDENTS' CLASSICAL LEARNING COMPLETENESS

\begin{tabular}{|c|c|c|}
\hline Class A & Class B & Class C \\
\hline $96 \%$ & $89 \%$ & $89 \%$ \\
\hline
\end{tabular}




\section{Feedback stage}

Judging from the social system, the teacher evaluates and revises the interaction process of individual learners with the surrounding environment as a learning resource. This fact is done because at the first two meeting students have not fully been able to complete the individual assignments that have been given, so the teacher provides alternative assignments when they are in the classroom. In terms of the principle of reaction in the social studies learning model based on cultural intelligence, the teacher has played a role as a facilitator, the teacher invites students to be directly involved with various learning sources through gathering information related to learning materials, namely through interviews in the community. Judging from the support system, the instructions in the LKPD at the first two meetings were still not well mastered by students. Thus, the teacher conducts a discussion process with peers and then makes improvements according to the perceived problems. Instructional impact and accompanying impact as a result of the evaluation and revision process carried out, the level of student involvement and learning outcomes has increased quite significantly.

Based on the results of interviews with teachers and students on the social studies learning model based on cultural intelligence, positive results were obtained, namely that teachers and students felt very helpful in understanding the subject matter. Thus, it can be said that the learning model has met the requirements for feasibility as a learning model. Therefore, the social studies learning model based on cultural intelligence is very feasible if it is applied to class and school situations with different categories, especially in supporting the success of students in understanding cultural diversity material, increasing the involvement of students in various activities that support their success in understanding, increase motivation, the spirit of cooperation and the process of adjustment with other students in situations of ethnic and cultural diversity.

\section{E. Learning Stage}

The implementation of the social studies learning model based on cultural intelligence experiences development and improvements at each stage of the model according to the constraints felt by the teacher. Experience activities in the social studies learning model based on cultural intelligence are carried out through the involvement of students in various field assignments, namely conducting observations and interviews in their respective environments that are related to diversity in society. The process of knowledge construction through interaction with the environment shows that learning leads to active individual involvement.

In the experience stage as an initial stage, students are given the opportunity to experience and be in a situation of diversity. Thus, the social studies learning model based on cultural intelligence is a model that is responsive to cultural differences and diversity, encourages the formation of mutual respect for differences, respects minority groups as part of community groups, and tries to bridge the relationship between the learning conditions of students in the home environment and the learning conditions. in the classroom. The second stage of reflection is the stage where students reexpress the information obtained. During the reflection process carried out by students in the cultural intelligence learning model, the ability to re-express the information obtained can be done by most students well. The ability of students is the result of concrete experiences by utilizing a contextual environment as an authentic learning process. The third is sharing activities carried out by each student conveying the information and knowledge they get through interviews or field observations to other friends in the group.

The fourth is the teamwork stage. The social studies learning model based on cultural intelligence refers to the principle that allows students to be in a state of equality without distinguishing gender, ethnicity, ethnicity, religion, cultural background and abilities. Students are exposed to issues of cultural diversity, religion and ethnicity. Through teamwork, students are trained to be able to mingle and help each other in completing group assignments together so that learning becomes more meaningful. And the fifth stage of the social studies learning model based on cultural intelligence is the presentation of the work carried out in turns in each group. Information communicated through presentation activities is the result of the process of gathering and obtaining information, the process of analyzing, the process of identifying, and the process of processing this information into new knowledge that must be conveyed to other students.

\section{F. Discussion \\ Input Stage}

The dominance of the teacher in delivering material to students is in stark contrast to the experience-based learning model, which is one of the social learning models. Implementing experiential learning activities requires teachers and students to change their mindset about teaching and learning. Their actions should shift from a teachercentered approach to a learner-centered approach [12]. One of the important principles of educational psychology is that teachers should not only impart knowledge to students. Learners must develop knowledge in their own minds. Teachers can facilitate this process by making information meaningful and relevant to students, providing opportunities for them to find and apply their own ideas, and teaching how they should learn [13]. Through the social studies learning model based on cultural intelligence, students become active and constructive main actors. Students learn in various forms of interaction with learning resources both inside and outside the classroom. Students learn from the surrounding environment, study, dig up information, and then discuss it with other students in the class. Social studies education is a study that discusses how a person will interact with his environment. Teaching about social life is important because it is the basis for a child to live [14].

\section{Process Stage}

The implementation of the social studies learning model based on cultural intelligence refers to the process expected in the 2013 Curriculum with several learning activities, namely observing, questioning, collecting and organizing, and communicating. The activity of observing in the cultural intelligence model is carried out through assignments given to individual students to make observations in their respective environments related to the subject matter they are going to learn. The activity of asking questions in the social studies learning model based on cultural intelligence is carried out 
through the process of interviewing parents and the community around the students' environment related to individual assignments given by the teacher to extract information related to the diversity around them. In addition, the students carried out questioning activities after the cultural performance process was carried out by several students in front of the class. Thus, one of the suitable learning models applied to the characteristics of social studies learning in instilling a tolerance value is a learning model characterized by an increase in creative and critical thinking skills and a learning process that must provide opportunities for all students to develop their potential so that the learning process will direct students. become active with the learners' own experiences [15].

The activities of collecting and organizing in the cultural intelligence learning model, students are given the opportunity to carry out the process of reflection and sharing. Reflection activities are carried out to train students to re-express the information that has been obtained by writing as much information as possible on post-it paper. Meanwhile, sharing is a process of exchanging information both individually and in groups through visiting work activities in the classroom. The activity of communicating the results in the cultural intelligence learning model is carried out through the process of presenting the work of each group in front of the class. The presentation of the results of each group is the final process of the cultural intelligence learning step so that students can make conclusions about the learning material that has been carried out in the classroom.

In line with observing activities in the cultural intelligence learning model, in the 2013 Curriculum observing activities, the teacher opens widely and varies giving students the opportunity to make observations through activities: seeing, listening, listening, and reading. Teachers facilitate students to make observations, train them to pay attention (see, read, hear) important things from an object or object. Around the world, twenty-first century middle classrooms are based on a growing diversity of cultures. Educators who use culturally responsive curricula with a proposed framework of existential pedagogy for secondary education seek to promote the academic success of culturally diverse learners [16]. In a culturally responsive curriculum, existential pedagogy holistically engages learners to critically reflect on how knowledge is constructed in culture while exploring what it means to live as individuals in a diverse world. As a result, culturally diverse classrooms are beginning to understand human experience in a more significant context and explore existential concerns through cultural differences. Existential pedagogy is an integral part for multicultural secondary educators and students to work for social justice by bridging the gap between cultural differences.

\section{Output Stage}

Based on the results of the process assessment of learning activities that have been carried out, the overall social studies learning process based on cultural intelligence is more directed at student center learning. Students become the subject of learning while the teacher is the facilitator whose task is to provide instructions and control and evaluate the learning process that occurs. In the social system of the cultural intelligence learning model, the interaction of students and teachers with various learning sources has seen an increase. The increase in student interaction patterns is in line with Vygotsky's key proposition which states that children's cognitive development is influenced by interactions with other people, especially parents, other children, teachers, and mentors in the child's social environment \{17].

Thus, the social studies learning model based on cultural intelligence is a learning model that places students as learning subjects, brings students closer to real situations, and involves students in various learning activities and actions. The learning model through action can stimulate student involvement in learning activities and is a prerequisite that can be used to acquire knowledge and skills and is a mediator of the achievement of expected learning outcomes [18]. The instructional impact that arises from the process of implementing the social studies learning model based on cultural intelligence is an increase in the learning motivation of students so that it has an impact on increasing learning outcomes obtained. Enjoying the learning process with other people of different cultures, having positive behavior and respecting the differences that exist are the accompanying effects of the cultural intelligence-based social studies learning model.

\section{Feedback stage}

The feedback stage is the stage of making improvements to the steps in learning that are still needed. Improvements are made to maximize the application of learning steps to match what is contained in the lesson plan. Improvements to the learning design are carried out in an effort to maximize the ability of teachers to carry out syntax or learning steps. Effective feedback plays a large role in the teaching-learning process and the performance of learners. This becomes possible when the teacher has a positive perception of feedback and practices it very well [19]. The results of his research show that most of the teachers' perceptions and feedback practices to improve student learning are good. However, there are gaps in using feedback as a learning objective rather than for assessment. Thus, if the teacher has good perceptions and practices, the use of feedback for learning purposes is neglected. Therefore, training teachers in the effective use and provision of feedback is the main task of schools and education offices at regional and national levels.

The characteristic of feedback that focuses on learning is an emphasis on the impact of the feedback, how to assess the impact so that it is well understood, and how the effects of feedback can be detected in subsequent behavior and work [20]. Therefore, it is important to design feedback practices so that the teacher can determine whether the main problem faced has been made improvements in the next activity. Improvements to the learning design at each meeting emphasize the ability of the teacher to understand and translate learning steps.

\section{Learning Stage}

At the learning stage, the activities of teachers and students during the learning process seem to have increased and the difficulties faced while implementing the cultural intelligence-based social studies learning model can be minimized. This fact can be seen from the increase in learning outcomes and a portion of the level of involvement of students inside and outside the classroom. The role of the learning 
environment is one of the keys to success in the learning process. Through interviews and field observations, students dig up information about the diversity of ethnicities, religions and ethnic groups in their respective environments. When the school population becomes increasingly diverse with students from different ethnic, cultural and linguistic backgrounds, there is a need to implement more responsive learning by utilizing the cultural capital of these students into the learning process [21].

The process of building meaning in learning so as to form learners' knowledge and awareness of the diversity of religions, cultures and ethnicities in the cultural intelligence learning model is carried out through the reflection stage. The results of research on students' reflection activities about situations and conditions as well as self-awareness show that the value of various learning and scaffolded experiences and strength in understanding situations and conditions can increase the ability to observe and increase reflective awareness [22].

The study of knowledge sharing continues to attract attention because knowledge sharing has been identified as an effective learning and research approach [23]. As an effective part of the steps in the cultural intelligence learning model, sharing activities are an effort to strengthen students' understanding and knowledge of diversity material that has been obtained through the process of experience and reflection. The sharing process in the social studies learning model based on cultural intelligence is in accordance with the critical pedagogy theory that critical pedagogy "involves empowering students to share responsibility for their education through the process of raising problems based on collective experiences in the world around them.

Furthermore, providing opportunities for students to work together allows for an increase in deeper understanding of the subject matter because students have the opportunity to solve problems together. Teamwork in the context of cultural diversity is in line with 21 st century skills, namely life and career skills that students must be able to carry out social and inter-cultural interactions, where students must be able to interact and work effectively with diverse groups [24]. Thus, the teamwork process in the cultural intelligence learning model allows students to collaborate and work together in various tasks and responsibilities, build empathy for others, communicate during the discussion process and present an attitude of respecting differences among students. The results of teamwork are very important to be communicated to all groups in the class. Thus, presentation is the process of communicating the work or information orally as knowledge obtained from the results of discussions through teamwork in each group. Oral presentation assignments are beneficial for all learners but especially beneficial for those with limited experience speaking in front of a larger audience [25].

\section{CONCLUSION}

The implementation of the social studies learning model based on cultural intelligence on the material of social mobility and plurality of Indonesian society can increase cultural intelligence and student learning outcomes as part of their understanding of the conditions and socio-cultural problems that occur in the community where they are located. The learning success of students cannot be separated from an active and constructive role as the main actor in following instructions, exploring and constructing their own knowledge through the learning activities they do both inside and outside the classroom. As a constructive main actor, increased cultural intelligence and student learning outcomes have met the criteria set as an indicator of success in implementing a cultural intelligence-based social studies learning model.

\section{ACKNOWLEDGMENT}

Thank you to the social studies teacher and principal of SMPN 4 Labuhan Badas, Sumbawa Regency for their cooperation and willingness to take the time to implement the social studies learning model based on cultural intelligence in class VIII. Thank you also to the research team who participated so that the research carried out could run according to the predetermined time.

\section{REFERENCES}

[1] Enok Maryani, "Pengembangan keterampilan sosial melalui pembelajaran geografi," pp. 1-24.

[2] D. Desyandri, "Nilai-Nilai Kearifan Lokal untuk Menumbuhkembangkan Literasi Budaya di Sekolah Dasar," Sekol. Dasar Kaji. Teor. dan Prakt. Pendidik., vol. 27, no. 1, pp. 1-9, 2018, doi: 10.17977/um009v27i12018p001.

[3] M. Saleh, "BUDAYA ' ILA ': HARGA DIRI ORANG SAMAWA," pp. 15-34.

[4] S. Iskandar, "Inter-Ethnic Conflict Samawa and Bali in Sumbawa , Indonesia," vol. 3, no. 20, pp. 40-45, 2013.

[5] H. N. Fard, M. Mahboubi, B. Saeidipour, and B. Rastegari, "Influence of cultural intelligence on problem solving procedure by Kermanshah secondary school teachers in the academic year 2014-15," no. 4, pp. 69-74, 2015.

[6] L. Van Dyne, S. Ang, and T. M. Nielsen, "Cultural ntelligence," in International encyclopedia of organization studies, no. c, 2007, pp. 345-350.

[7] Danoebroto and S. Wulandari, "Model Pembelajaran Matematika Berbasis Pendidikan Multikultural," J. Pembang. Pendidik. Fondasi dan Apl., vol. 1, no. 1, 2019, doi: 10.21831/jppfa.v1i1.1054.

[8] A. Miftachul Hudha, M. Amin, S. S. Bambang, and dun Akbar, "Telaah Model-Model Pembelajaran Dan Sintaksnya Sebagai Upaya Pengembangan Model Pembelajaran 'Oidde' Study of Instructional Models and Syntax As an Effort for Developing 'Oidde' Instructional Model," vol. 2, pp. 109-124, 2016

[9] A. Isman, "Instructional design in education: New model," Turkish Online J. Educ. Technol., vol. 10, no. 1, pp. 136-142, 2011, [Online]. Available: http://files.eric.ed.gov/fulltext/EJ926562.pdf.

[10] J. S. Matthew B. Miles, A. Michael Huberman, qualitative data analysis. SAGE Publication Ltd, 1992.

[11] S. Ang and L. Van Dyne, "Ang \& Van Dyne 2008 Handbook Ch 1 Conceptualization of CQ.pdf," Conceptualization of Cultural Intellegence. pp. 3-13, 2008.

[12] O. Duong and T. Kim, "Organizing Experiential Learning Activities for Development of Core Competences of Technical Students in Vietnam," vol. 7, no. 1, pp. 230-238, 2019, doi: 10.13189/ujer.2019.070129.

[13] R. E. Slavin, Psikologi Pendidikan. Teori dan Praktik, Sembilan. Jakarta: PT Indeks, 2011.

[14] Gustina, A. Ananda, and A. Kosasih, "Factors in Using Speech Method in Social Subject," vol. 178, no. ICoIE 2018, pp. 1-3, 2019.

[15] R. Manurung, M. S. Sumantri, and E. Utomo, "Enhancing Tolerance Character through Problem Based Learning Model ( Pbl ) based on Simulation of Social Studies Subject with the of Themes of Diversity in My Country," vol. 6, pp. 835-839, 2018.

[16] F. N. Hakim, D. T. Kartono, and A. Demartoto, "INTERNALIZATION MULTICULTURAL EDUCATION FOR THE PREVENTION,” vol. 2, no. 1, pp. 129-138, 2018. 
[17] C. Kivunja, "Do You Want Your Students to Be Job-Ready with 21st Century Skills? Change Pedagogies: A Pedagogical Paradigm Shift from Vygotskyian Social Constructivism to Critical Thinking, Problem Solving and Siemens' Digital Connectivism," Int. J. High. Educ., vol. 3, no. 3, pp. 81-91, 2014, doi: 10.5430/ijhe.v3n3p81.

[18] N. Pino-james, "Evaluation of a pedagogical model for student engagement in learning activities," Educ. Action Res., vol. 0792, no. August, pp. 1-24, 2017, doi: 10.1080/09650792.2017.1354771.

[19] A. A. Dessie and A. A. Sewagegn, "Moving Beyond a Sign of Judgment: Primary School Teachers 'Perception and Practice of Feedback," vol. 12, no. 2, pp. 51-66, 2019.

[20] N. Winstone, D. Boud, and N. Winstone, "Exploring cultures of feedback practice : the adoption of learning-focused feedback practices in the UK and Australia learning-focused feedback practices in the UK and Australia," High. Educ. Res. Dev., vol. 0, no. 0, pp. 1-15, 2018, doi: 10.1080/07294360.2018.1532985.

[21] P. Wachira and J. Mburu, "Culturally Responsive Mathematics Teaching and Constructivism: Preparing Teachers for Diverse
Classrooms," Multicult. Learn. Teach., pp. 1-8, 2017, doi: 10.1515/mlt-2016-0023.

[22] T. Blakemore, K. Agllias, T. Blakemore, and K. Agllias, "Student Reflections on Vulnerability and Self- awareness in a Social Work Skills Course Student Re fl ections on Vulnerability and Selfawareness in a Social Work Skills Course," vol. 0748, pp. 20-33, 2019, doi: 10.1080/0312407X.2018.1516793.

[23] F. N. Koranteng and I. Wiafe, "Factors that Promote Knowledge Sharing on Academic Social Networking Sites : An Empirical Study," 2018.

[24] E. Y. Wijaya, D. A. Sudjimat, A. Nyoto, and U. N. Malang, "Transformasi pendidikan abad 21 sebagai tuntutan pengembangan sumber daya manusia di era global," vol. 1, pp. 263-278, 2016.

[25] E. R. Shauki and H. Benzie, "Meeting threshold learning standards through self-management in group oral presentations : observations on accounting postgraduate students," Account. Educ., vol. 0, no. 0, pp. 119, 2017, doi: 10.1080/09639284.2017.1300777. 